\title{
PENGARUH PENGGUNAAN EKSTRAK DAUN SALAM (SYZYGIUM POLYANTHUM) DALAM AIR MINUM TERHADAP KECERNAAN NUTRIEN RANSUM DAN RETENSI NITROGEN ITIK LOKAL JANTAN
}

\section{THE EFFECT OF USE OF SALAM LEAF EXTRACT (SYZYGIUM POLYANTHUM) IN DRINKING WATER ON NUTRIENT DIGESTIBILITY AND NITROGEN RETENTION OF MALE LOCAL DUCK}

\author{
FD. Harvianto ${ }^{1 a}$, Anggraeni, D. Sudrajat
}

${ }^{1}$ Program studi Peternakan Fakultas Pertanian Universitas Djuanda Bogor, Jl. Tol Ciawi No. 1, Kotak Pos 35 Ciawi, Bogor 16720.

aKorespondensi: Finsa Dwinanda, E-mail: finsa.dwinanda.harvianto@unida.ac.id

\begin{abstract}
Ducks is one of the poultry that have the potential to be an alternative in meeting the social demand for poultry meat. Based on research that has been done to contain bay leaves steroid compounds, phenolics, saponins, flavonoids and alkaloids. This study was aimed at assessing the effects of the inclusion of bay leaf (Syzygium polyanthum) extract in drinking water on nutrient digestibility and nitrogen retention of rations in local male ducks. The study was conducted at the Trial Farm of Djuanda University, Bogor from 18 March to 13 May 2019. Thirty-five male Mojosari Alabio ducks aged 8 weeks were used. Ducks were fed commercial rations. A completely randomized design with 3 treatments and 6 replicates was used. Treatments consisted of $0 \%$ bay leaf extract (control, R0), 4\% bay leaf extract (R1), and 8\% bay leaf extract (R2). Data were subjected to an analysis of variance and a Duncan test. Measurements were taken on digestibility of dry matter, fiber, crude fat, ash, and nitrogen free extract and nitrogen retention. It was shown that the inclusion of bay leaf extract of up to $8 \%$ in drinking water gave significant effects $(\mathrm{P}<0.05)$ on nitrogen retention but not on nutrient digestibility.
\end{abstract}

Key words: Bay leaf, Mojosari Alabio duck, digestibility, nitrogen retention

\begin{abstract}
ABSTRAK
Itik merupakan salah satu ternak unggas yang memiliki potensi untuk dijadikan alternatif dalam pemenuhan kebutuhan masyarakat terhadap daging unggas. Berdasarkan penelitian yang telah dilakukan daun salam mengandung senyawa steroid, fenolik, saponin, flavonoid, dan alkaloid. Penelitian ini bertujuan menguji pengaruh penggunaan ekstrak daun salam (Syzygium polyanthum) terhadap kecernaan nutrien ransum dan retensi nitrogen itik lokal jantan. Penelitian dilaksanakan pada 18 Maret sampai 13 Mei 2019 dikandang peternakan Universitas Djuanda Bogor. Ternak yang digunakan dalam penelitian ini adalah itik Mojosari Alabio (MA) umur 8 minggu sebanyak 35 ekor. Pakan yang diberikan merupakan pakan komersil. Penelitian menggunakan rancangan acak lengkap (RAL) yang terdiri dari 6 ulangan. Perlakuan yang diberikan $\mathrm{R} 0=0 \%$ ekstrak daun salam (kontrol), $\mathrm{R} 1=4 \%$ ekstrak daun salam, R2=8\% ekstrak daun salam. Data yang diperoleh dianalisis menggunakan Analisys of variance (ANOVA) bila data menunjukkan hasil berbeda nyata $(\mathrm{P}<0,05)$ dilanjutkan dengan uji Duncan. Peubah yang diamati dalam penelitian yaitu kecernaan bahan kering, serat kasar, lemak kasar, abu, bahan ekstrak tanpa nitrogen dan retensi nitrogen. Kesimpulan dari penelitian menunjukkan pemberian ekstrak daun salam sampai tingkat $8 \%$ berpengaruh nyata terhadap retensi nitrogen dan tidak berpengaruh terhadap kecernaan bahan kering, serat kasar, lemak kasar, abu, bahan ekstrak tanpa nitrogen.

Kata Kunci : Daun Salam, Itik Mojosari Alabio, Kecernaan, Retensi Nitrogen.
\end{abstract}


FD Harvianto, Anggraeni, D Sudrajat.2020. Pengaruh Penggunaan Ekstrak Daun Salam (Syzygium Polyanthum) Dalam Air Minum Terhadap Kecernaan Nutrien Ransum Dan Retensi Nitrogen Itik Lokal Jantan. Jurnal Peternakan Nusantara 6(1):41-46.

\section{PENDAHULUAN}

Itik merupakan salah satu ternak unggas yang memiliki potensi untuk di jadikan alternatif dalam memenuhi kebutuhan masyarakat terhadap daging unggas. Populasi itik di Indonesia mengalami sedikit peningkatan dari tahun 2014 hingga 2015 sebesar $0.12 \%$. Populasi itik tersebut masih terbilang rendah yaitu pada tahun 2015 hanya berkisar 45321 956 ekor dengan total produksi daging itik yaitu 34854 ton (Ditjennak 2016). Ternak itik memiliki potensi untuk dikembangkan sebagai penghasil daging dikarenakan salah satunya itik memiliki daya adaptasi yang baik. Permasalahan daging itik yaitu permintaan daging meningkat dan masih adanya konsumen yang belum terbiasa mengkonsumsi daging itik karena bau daging yang anyir/amis. Faktor yang mempengaruhi bau amis adalah pakan, genetic dan pengolahan (Matitaputty et al 2010). Oleh karena itu diperlukan bahan alternatif dalam upaya meningkatkan performa dan produktivitas itik yang optimal.

Di Indonesia bahan alam banyak digunakan secara turun temurun sebagai obat tradisional untuk mengatasi berbagai penyakit (Elfahmi et al 2014) salah satunya tamanan yang sering digunakan yaitu daun salam. Masyarakat sudah banyak mengenal daun salam dan biasanya dimanfaatkan sebagai rempah-rempah atau bumbu dapur penyedap masakan dikarenakan memiliki aroma khas. Selain itu, salam sering digunakan untuk pengobatan alternatif karena tumbuhan ini mudah didapatkan dan banyak terdapat dimasyarakat. Berdasarkan penelitian daun salam mempunyai senyawa seperti flavonoid, saponin, alkaloid, steroid dan fenolik (Liliwirianis et al 2011).

\section{MATERI DAN METODE}

\section{Materi}

Penelitian dilaksanakan pada bulan Maret Mei 2019, bertempat di kandang peternakan Program Studi Peternakan Fakultas Pertanian
Universitas Djuanda Bogor, Jalan Tol Ciawi No. 1 Bogor. Jawa Barat.

Kandang yang digunakan adalah kandang baterai ukuran $50 \mathrm{~cm} \mathrm{X} 50 \mathrm{~cm}$ yang dilengkapi tempat pakan, minum. Alat pemeliharaan seperti sapu lidi, lampu 40 watt, ember dan alat dokumentasi. Ternak yang digunakan dalam penelitian sebanyak 72 ekor itik MA jantan yang dipelihara mulai DOD (Days Old Duck). Itik yang digunakan berasal dari Balai Penelitian Ternak, Jl. Raya Veteran III Banjar Baru, Ciawi, Kabupaten Bogor. Pakan komersil yang digunakan Charoend Pokhpand BR 11. Daun salam berasal dari Bogor dan Cikarang.

\section{Perlakuan}

Perlakuan yang diberikan selama penelitian yaitu: $\mathrm{R} 0=$ pemberian air minum $(3000 \mathrm{ml})$ tanpa ekstrak daun salam (kontrol). R1 = pemberian air minum (3000 ml) mengandung $4 \%$ ekstrak daun salam. $\mathrm{R} 2=$ pemberian air minum (3000 ml) mengandung 8\% ekstrak daun salam.

\section{Rancangan Percobaan}

Penelitian menggunakan rancangan acak lengkap (RAL) dengan 3 perlakuan dan 6 ulangan. Setiap ulangan terdiri atas 4 ekor itik. Sehingga jumlah itik yang digunakan sebanyak 72 ekor.

\section{Peubah yang Diamati}

Peubah yang diamati terdiri atas: 1) konsumsi

Kecernaan Bahan Kering

$=\frac{\text { konsumsi BK ransum }- \text { kadar BK ekskreta }(g)}{\text { konsumsi BK ransum }(g)} \times 100 \%$

Kecernaan Serat Kasar

$=\frac{\text { konsumsi SK ransum }- \text { kadar SK ekskreta }(g)}{\text { konsumsi SK ransum }(g)} \times 100 \%$

Kecernaan Lemak Kasar

$=\frac{\text { konsumsi LK ransum }- \text { kadar LK ekskreta }(g)}{\text { konsumsi LK ransum }(g)} \times 100 \%$

Kecernaan Abu

$=\frac{\text { konsumsi Abu ransum - kadar Abu ekskreta }(g)}{\text { konsumsi Abu ransum }(g)} \times 100 \%$ 
Kecernaan BETN

$=\frac{\text { konsumsi BETN ransum }- \text { kadar BETN ekskreta }(g)}{\text { konsumsi BETN ransum }(g)} \times 100 \%$

Retensi Nitrogen

$=\frac{\text { konsumsi } N \text { ransum }- \text { kadar } N \text { ekskreta }(g)}{\text { konsumsi } N \text { ransum }(g)} \times 100 \%$

\section{Analisis Data}

Data yang diperoleh dianalisis dengan sidik ragam (ANOVA) dan jika perlakuan berpengaruh nyata terhadap peubah yang diamati maka analisis dilanjutkan dengan uji lanjut jarak ganda Duncan dengan menggunakan bantuan piranti program SPSS 16.

\section{Prosedur Pelaksanaan}

Sebelum pemeliharaan dimulai dilakuan pencucian kandang dan disiapkan sumber penerangan, tempat pakan dan minum. Sisi-sisi kandang diberikan terpal agar suhu dalam kandang tidak cepat berubah. Alas kandang dipasang berupa seng untuk menampung ekskreta.

Itik yang digunakan sebanyak 78 ekor dengan umur 1 hari dalam keadaaan sehat, mata cerah, bergerak aktif dan tidak cacat. Itik yang baru datang diberikan berikan air gula dan dilakukan masa adaptasi lingkungan tanpa perlakuan. Itik yang berumur 5 hari mulai diberikan adaptasi ekstrak daun salam sebanyak $2 \%$ dan pada hari ke 7 mulai dilakukan perlakuan.

Daun salam yang digunakan adalah daun salam yang segar dengan ciri-ciri daun masih berwarna hijau dan mempunyai aroma khas yang masih kuat. Pertama pisahkan daun salam dari batang lalu cuci bersih, selanjutnya iri tipis daun salam menggunakan pisau. Masukan daun salam dan air ke dalam panci dengan perbandingan $100 \mathrm{~g}$ daun salam +2 liter air. Rebus dengan api kecil selama 20 menit setelah mendidih. Dinginkan ekstrak daun salam lalu saring sebelum digunakan. Pembuatan larutan daun salam dilakukan setiap 3 hari sekali untuk menjaga kesegarannya, stok ekstrak daun salam disimpan dalam refrigerator.

Kegiatan yang dilakukan pagi hari yaitu menimbang sisa pakan dan minum, membersihkan alas kandang, menyapu, menganti air minum dan menimbang pakan yang akan diberikan. Pakan diberikan sehari satu kali pukul 09.00 WIB. Itik diberi minum perlakuan sesusai nomor ulangan dengan dilakukan pengacakan unit penelitian.
Pengambilan ekskreta dilakukan selama 3 hari pada akhir masa pemeliharaan. Ekskreta ditampung dengan karpet plastik yang dipasang di alas kotoran kandang itik. Penampungan ekskreta dilakukan selama 24 jam setiap harinya. Ekskreta yang terkumpul di timbang bobotnya lalu di ambil 10\% dari berat totalnya. Ekskreta $\quad 10 \%$ tersebut dilakukan penyemprotan $\mathrm{H} 2 \mathrm{SO} 4$ 0,01N untuk menghindari penguapan nitrogen. Setiap perlakuan dimasukkan dalam kantong yang berbeda, diberi label. Sampel ekskreta yang diperoleh dikeringkan dalam oven dengan suhu $60 \stackrel{\circ}{\circ} \mathrm{C}$ selama 50 menit untuk mendapatkan sampel kering yang akan digunakan untuk analisis proksimat ekskreta.

\section{HASIL DAN PEMBAHASAN}

\section{Kecernaan Bahan Kering}

Berdasarkan analisis ragam perlakuan pemberian ekstrak daun salam tidak berpengaruh nyata $(\mathrm{P}>0,05)$ terhadap kecernaan bahan kering. Perlakuan pemberian ekstrak daun salam menghasilkan kecernaan bahan kering tertinggi R0 yaitu $85.88 \pm 1.53 \%$ kemudian diturut ikuti dengan R2 85.30 $1.22 \%$ dan R1 84.40 $\pm 1.98 \%$.

Tabel 1 konsumsi bahan kering dan kecernaan bahan kering pada itik yang diberi ekstrak daun salam.

\begin{tabular}{lll}
\hline Perlakuan & $\begin{array}{l}\text { Konsumsi BK } \\
(\mathrm{g})\end{array}$ & $\begin{array}{l}\text { Kecernaan } \\
\mathrm{BK}(\%)\end{array}$ \\
\hline R0 & $429.90 \pm 56.20$ & $85.88 \pm 1.53$ \\
R1 & $329.45 \pm 56.24$ & $84.40 \pm 1.98$ \\
R2 & $407.68 \pm 128.43$ & $85.30 \pm 1.22$ \\
\hline
\end{tabular}

Keterangan: Data hasil kecernaan bahan kering menunjukan hasil tidak berbeda nyata $(\mathrm{P}>0,05)$. $\mathrm{R} 0=0 \%$ ekstrak daun salam, $\mathrm{R} 1=4 \%$ ekstrak daun salam, R2 = 8\% ekstrak daun salam

Pemberian ekstrak daun salam dalam air minum tidak memberikan pengaruh yang signifikan terhadap kecernaan bahan kering. Perbedaan tingkat (KCBK) dipengaruhi oleh beberapa faktor antara lain jenis dan jumlah pakan yang dikonsumsi, kondisi ternak, kemampuan ternak dalam mencerna bahan pakan, dan lingkungan (Nelwida 2009)

\section{Kecernaan Serat Kasar}

Serat kasar terdiri dari selulosa, hemiselulosa dan lignin yang mana sebagian besar unggas tidak dapat mencerna dan bersifat 
sebagai pengganjal (Wahju, 2004). Berdasarkan hasil analisis ragam kecernaan serat kasar itik dengan pemberian ekstrak daun salam dalam air minum menunjukan pengaruh tidak berbeda nyata $(\mathrm{P}>0,05)$ dimana kecernaan SK tertinggi terdapat pada R1 yaitu sebesar $75.22 \pm 2.41 \%$ diikuti perlakuan R2 $70.98 \pm 4.39 \%$ dan kecernaan terendah terdapat pada perlakuan R0 yaitu sebesar $69.48 \pm 6.88$ $\%$.

Tabel 2 konsumsi SK dan kecernaan SK pada itik yang diberi ekstrak daun salam

\begin{tabular}{ccc}
\hline Perlakuan & $\begin{array}{c}\text { Konsumsi } \\
\text { SK }(\mathrm{g})\end{array}$ & $\begin{array}{c}\text { Kecernaan } \\
\text { SK }(\%)\end{array}$ \\
\hline R0 & $15.71 \pm 2.06$ & $69.48 \pm 6.88$ \\
R1 & $12.07 \pm 2.06$ & $75.22 \pm 2.41$ \\
R2 & $14.91 \pm 4.70$ & $70.98 \pm 4.39$ \\
\hline
\end{tabular}

Keterangan: Data hasil kecernaan serat kasar menunjukan hasil tidak berbeda nyata $(\mathrm{P}>0,05) . \mathrm{R} 0=0 \%$ ekstrak daun salam, $\mathrm{R} 1=$ $4 \%$ ekstrak daun salam, R2=8\% ekstrak daun salam.

Pada penelitian ini pakan yang digunakan adalah ransum komersial dimana kandungan serat kasar pada setiap perlakuan sama, sehingga kecernaan serat kasar pada setiap perlakuan perbedaannya tidak terlalu signifikan. Kecernaan yang lebih tinggi pada perlakuan R1 menujukan kecernan SK lebih baik dari pada R0 dan R2. Menurut Tillman et al. (2005) menyatakan bahwa kandungan serat kasar dalam ransum mempengaruhi kecernaan serat kasar dan jumlah SK yang dikonsumsi

\section{Kecernaan Lemak Kasar}

Berdasarkan analisis ragam perlakuan pemberian ekstrak daun salam tidak berpengaruh nyata $(\mathrm{P}>0,05)$ terhadap kecernaan lemak kasar dimana kecernaan SK tertinggi terdapat pada R1 yaitu sebesar $92.85 \pm 0.64 \%$ diikuti perlakuan R0 $92.38 \pm 2.55$ $\%$ dan kecernaan terendah terdapat pada perlakuan R2 yaitu sebesar 91.96 $\pm 2.41 \%$. Hasil ini lebih besar dari penelitian (Maharani et al 2018) dimana nilai kecernaan lemak kasar itik persilangan Mojosari-Peking yang diberikan limbah cair pemindangan ikan dalam ransum pada yaitu antara 76,22 - 83,45\% .
Tabel 3 konsumsi lemak kasar dan kecernaan lemak kasar pada itik yang diberi ekstrak daun salam.

\begin{tabular}{ccc}
\hline Perlakuan & $\begin{array}{c}\text { Konsumsi } \\
\text { LK }(\mathrm{g})\end{array}$ & $\begin{array}{c}\text { Kecernaan } \\
\text { LK }(\%)\end{array}$ \\
\hline R0 & $26.43 \pm 3.44$ & $92.38 \pm 2.55$ \\
R1 & $20.27 \pm 3.45$ & $92.85 \pm 0.64$ \\
R2 & $25.06 \pm 7.89$ & $91.96 \pm 2.41$ \\
\hline
\end{tabular}

Keterangan: Data hasil kecernaan lemak kasar menunjukan hasil tidak berbeda nyata $(\mathrm{P}>0,05) . \mathrm{R} 0=0 \%$ ekstrak daun salam, $\mathrm{R} 1=4 \%$ ekstrak daun salam, R2 $=8 \%$ ekstrak daun salam

Mekanisme penyerapan lemak terjadi pada usus halus yaitu pada bagian duodenum. lipase adalah enzim yang mencerna lemak yang sebagian besar dihasilkan oleh pankreas. Pencernaan lemak dibantu garam-garam empedu dan cairan pankreas bekerja mengemulsifikasi lemak sebelum dicerna (Rizal 2006). Lemak yang berbentuk emulsi dipecah oleh enzim lipase dari pankreas menjadi asam lemak dan gliserol sebagai hasil akhir pencernaan lemak.

\section{Kecernaan Abu}

Abu adalah zat anorganik dari sisa hasil pembakaran suatu bahan organik. Dalam proses pembakaran, bahan-bahan organik terbakar tetapi zat anorganiknya tidak. Kandungan abu dari suatu bahan menunjukkan kadar mineral dalam bahan tersebut.

Tabel 4 konsumsi abu dan kecernaan abu pada itik yang diberi ekstrak daun salam.

\begin{tabular}{ccc}
\hline Perlakuan & $\begin{array}{c}\text { Konsumsi } \\
\text { Abu (g) }\end{array}$ & $\begin{array}{c}\text { Kecernaan } \\
\text { Abu }(\%)\end{array}$ \\
\hline R0 & $26.18 \pm 3.44$ & $57.80 \pm 5.80$ \\
R1 & $20.07 \pm 3.42$ & $55.90 \pm 6.00$ \\
R2 & $24.85 \pm 7.82$ & $60.23 \pm 3.97$ \\
\hline
\end{tabular}

Keterangan: Data hasil kecernaan abu menunjukan hasil tidak berbeda nyata $(\mathrm{P}>0,05) . \mathrm{R} 0=0 \%$ ekstrak daun salam, $\mathrm{R} 1=4 \%$ ekstrak daun salam, R2 $=8 \%$ ekstrak daun salam.

Berdasarkan analisis ragam perlakuan pemberian ekstrak daun salam tidak 
berpengaruh nyata $(\mathrm{P}>0,05) \quad$ terhadap kecernaan abu. Perlakuan pemberian ekstrak daun salam yang menghasilkan kecernaan abu tertinggi R2 yaitu $60.23 \pm 3.97 \%$ kemudian diturut ikuti dengan R0 $57.90 \pm 6.00 \%$ dan R1 $55.90 \pm 6.00 \%$.

\section{Bahan Ekstrak Tanpa Nitrogen}

Berdasarkan analisis ragam perlakuan pemberian ekstrak daun salam tidak berpengaruh nyata $(\mathrm{P}>0,05)$ terhadap kecernaan bahan ekstrak tanpa nitrogen dimana kecernaan BETN tertinggi terdapat pada perlakuan R0 yaitu sebesar $89.76 \pm 1.02 \%$ diikuti perlakuan R2 89.21 $\pm 0.68 \%$ dan kecernaan terendah terdapat pada perlakuan R1 yaitu sebesar $88.76 \pm 1.02 \%$.

Tabel 5 konsumsi BETN dan kecernaan BETN pada itik yang diberi ekstrak daun salam.

\begin{tabular}{lll}
\hline Perlakuan & $\begin{array}{l}\text { Konsumsi } \\
\text { BETN }(\mathrm{g})\end{array}$ & $\begin{array}{l}\text { Kecernaan } \\
\text { BETN }(\%)\end{array}$ \\
\hline R0 & $271.45 \pm 35.49$ & $89.76 \pm 1.02$ \\
R1 & $208.07 \pm 35.54$ & $88.05 \pm 1.41$ \\
R2 & $257.43 \pm 81.12$ & $89.21 \pm 0.68$ \\
\hline
\end{tabular}

Keterangan: Data hasil kecernaan bahan ekstrak tanpa nitrogen menunjukan hasil tidak berbeda nyata $(\mathrm{P}>0,05)$. $\mathrm{R} 0=0 \%$ ekstrak daun salam, $\mathrm{R} 1=$ $4 \%$ ekstrak daun salam, R2 $=8 \%$ ekstrak daun salam.

Komponen (BETN) terbesar adalah karbohidrat nonstruktural, seperti pati, gulagula atau monosakarida (Budiman et al 2006). Menurut (Sutardi 2006) kandungan BETN suatu bahan pakan sangat tergantung pada komponen lainnya, seperti abu, air, serat kasar, protein kasar dan lemak kasar. Jika jumlah abu, air, lemak kasar, protein kasar dan serat kasar dikurangi dari 100, perbedaan itu disebut bahan ekstrak tanpa nitrogen (BETN).

\section{Retensi Nitrogen}

Tabel 6 konsumsi $\mathrm{N}$ dan kecernaan $\mathrm{N}$ pada itik yang diberi ekstrak daun salam.

\begin{tabular}{lcl}
\hline Perlakuan & $\begin{array}{c}\text { Konsumsi N } \\
(\mathrm{g})\end{array}$ & $\begin{array}{c}\text { Retensi N } \\
(\mathrm{g} / \mathrm{g})\end{array}$ \\
\hline R0 & $14.41 \pm 1.85$ & $0.85 \pm 0.054^{\mathrm{b}}$ \\
R1 & $11.05 \pm 1.85$ & $0.80 \pm 0.00^{\mathrm{a}}$ \\
R2 & $13.66 \pm 4.32$ & $0.80 \pm 0.00^{\mathrm{a}}$ \\
\hline
\end{tabular}

Keterangan: Superskrip huruf yang tidak sama dalam kolom menunjukan beda nyata $(\mathrm{P}<0,05) \mathrm{R} 0=0 \%$ ekstrak daun salam, $\mathrm{R} 1=4 \%$ ekstrak daun salam, R2 $=8 \%$ ekstrak daun salam.

Hasil penelitian menunjukan bahwa nilai ekskresi $\mathrm{N}$ ekskreta untuk semua perlakuan lebih rendah dari pada konsumsi nitrogennya (Tabel 6). Hal ini menunjukkan adanya nitrogen yang tertinggal dalam tubuh itik penelitian sehingga dapat dikatakan bahwa retensinya positif. Retensi nitrogen bernilai positif. (Hidayati dan Sujono 2006) apabila jumlah N yang dikonsumsi lebih besar dari pada $\mathrm{N}$ yang keluar, maka tercapai keseimbangan $\mathrm{N}$ yang positif, berarti $\mathrm{N}$ dari asam amino lebih banyak digunakan untuk pembentukan jaringan dan pertumbuhan.

Analisis ragam menunjukkan bahwa perlakuan memberikan pengaruh nyata $(\mathrm{P}<0,05)$ terhadap retensi nitrogen. Nilai retensi nitrogen pada perlakuan R0 lebih tinggi dibandingkan dengan R1 dan R2. Rendahnya nilai retensi nitrogen pada $\mathrm{R} 1$ dan $\mathrm{R} 2$ diduga karena adanya kandungan tanin dalam pada ekstrak daun salam. Tanin mengikat protein membentuk senyawa komplek sehingga kelarutan protein menurun dan sulit dicerna. Pada perlakuan R2 banyak protein yang tidak tercerna dikeluarkan melalui ekskreta. Hasil ini lebih tinggi dari penelitian (Sudrajat et al 2015) dimana nilai retensi nitrogen dengan penambahan larutan daun sirih dalam air minum yaitu antara 0.554 - 0.652 g. Nilai retensi nitrogen pada $\mathrm{R} 0$ yang lebih tinggi juga dikarena konsumi N R0 lebih tinggi dibanding R1 dan R2. Hal ini didukung oleh pernyataan Mirnawati et al. (2013) bahwa meningkatnya konsumsi nitrogen diikuti dengan meningkatnya retensi N. Retensi Nitrogen juga di pengaruhi konsumsi pakan sesuai dengan pendapat Wahju (2004), retensi nitrogen akan berkaitan erat dengan konsumsi ransum, semakin tinggi konsumsi ransum maka semakin tinggi pula nilai retensi $\mathrm{N}$.

\section{KESIMPULAN DAN IMPLIKASI}

\section{Kesimpulan}

Pemberian ekstrak daun salam dengan perlakuan 4 dan $8 \%$ tidak memberikan pengaruh nyata terhadap kecernaan bahan 
kering, serat kasar, lemak kasar, abu, dan bahan ekstrak tanpa nitrogen. Retensi nitrogen berpengaruh nyata pada pakan kontrol, dimana pakan kontrol lebih tinggi dibandingkan perlakuan menggunakan ekstrak daun salam.

\section{Implikasi}

Berdasarkan hasil penelitian disarankan untuk melaksanakan penelitian lebih lanjut menggunakan ekstraksi daun salam dengan metode pelarut etanol dan menggunakan itik fase grower atau finisher.

\section{DAFTAR PUSTAKA}

.[Balitnak] Balai Penelitian Ternak. 2006. Pendatang baru penghasil telur: Itik MA.Bogor: Unit Komersialisasi Teknologi Balitnak. www.balitnak.litbang.deptan.go.id (15 Mei 2006).

Budiman A. Tidi D. Budi A. 2006. Uji Kecernaan Serat Kasar dan Bahan Ekstrak Tanpa Nitrogen (BETN) dalam Ransum Lengkap Berbasis Hijauan Daun Pucuk Tebu (Saccharum Officinarum). Jurnal Ilmu Ternak UNPAD. Bandung. Vol 6 No 2, 132-135

[DITJENNAK]. 2016. Statistik Peternakan dan Kesehatan Hewan. Direktorat Jenderal Bina Produksi Peternakan, CV. Karya Cemerlang, Departemen Pertanian RI, Jakarta (ID).

Elfahmi, Herman W, Oliver K., 2014. Jamu: Indonesian Traditional Herbal Medicine Towards Rational Phytopharmacological Use. Journal Of Herbal Medicine, Volume IV, P. 5173.

Hidayati A, Sujono. 2006. Pengaruh penggunaan tepung buah mengkudu (Morinda citrifolia) terhadap pertambahan bobot badan dan tampilan pakan pada ayam pedaging. $J$. Protein. 13 (1): 10-16

Liliwirianis, Musa NLW, Zain WZ, Kasim Z, Karim SA. 2011. Preliminary Studies On Phytochemical Screening Of Ulam And Fruit
From Malaysia. EJournal of Chemistry, Volume VIII.

Maharani D. Mahfudz LD, Mangisah I. 2018. Pengaruh Penggunaan Limbah Cair Pemindangan Ikan dalam Ransum terhadap Kecernaan Protein, Lemak dan Energi Metabolis pada Itik Persilangan MojosariPeking. Jurnal Peternakan Indonesia Vol. 20 (1): 21-28

Matitaputty PR, Suryana. 2010. Karakteristik daging itik dan permasalahan serta upaya pencegahan off-flavor akibat oksidasi lipida. Wartazoa. 3(20): 130-138.

Mirnawati, B. Sukamto, Yunianto VD. 2013. Kecernaan protein, retensi nitrogen dan massa protein daging ayam broiler yang diberi ransum daun murbei (Morus alba L.) yang difermentasi dengan cairan rumen. JITP Vol. 3 No.1. Hal. 25-32.

Nelwida. 2009. Efek penggantian jagung dengan biji alpukat yang direndam air panas dalam ransum terhadap retensi bahan kering, bahan organik dan protein kasar pada ayam broiler. Jurnal Ilmiah Ilmu-Ilmu Peternakan. Volume 12 Nomor 1, 50 - 56.

Rizal Y. 2006. Ilmu Nutrien Unggas. Padang (ID): Univ. Andalas Pr

Sudrajat D, Kardaya D, Malik B, Abas. 2015. Pengaruh Larutan Daun Sirih Dalam Air Minum Sebagai Pengganti Antibiotik Terhadap Retensi Nitrogen Dan Energi Metabolis Ransum. Jurnal Peternakan Nusantara 2442-2541 Volume 1 Nomor 1.

Sutardi T. 2006. Landasan Ilmu Nutrisi Jilid I. Departemen Ilmu Makanan Ternak. Fakultas Peternakan. Institut Pertanian Bogor.

Tillman AD, Reksohadiprodjo S. Prawirokusumo Lebdosoekojo S. 2005. Ilmu Makanan Ternak Dasar. Gadjah Mada University Press, Yogyakarta

Wahju J. 2004. Ilmu Nutrisi Unggas. Cetakan ke lima. Gadjah Mada University Press, Yogyakarta 
